\title{
Az oktatási rendszer változásainak hatása az elmaradott vidéki térségekben élő fiatalok iskoláztatási és foglalkoztatási esélyeire
}

\author{
The impact of the transformations of the education system on \\ school and labour market prospects of young people in \\ lagging regions
}

\section{VELKEY GÁBOR}

VELKEY Gábor: tudományos munkatárs, osztályvezető, Közgazdaság- és Regionális Tudományi Kutatóközpont, Regionális Kutatások Intézete, Alföldi Tudományos Osztály; 5600 Békéscsaba, Szabó Dezső utca 42.; velkey.gabor@krtk.mta.hu; http://orcid.org/0000-0002-4677-0743

KULCSSZAVAK: szakképzési rendszer; térbeli-társadalmi egyenlőtlenségek; szelekció; szegregáció; periférikus térségek; fiatalok elhelyezkedési esélyei

ABSZTRAKT: G. Fekete Évával a kétezres évek elején folytattunk egy sok szempontból újszerű közös kutatást „Tartós munkanélküliség és kezelése vidéki térségekben” címmel. Tanulmányom első részében e kutatás tematikáját követve az elmaradott vidéki térségek mai foglalkoztatási helyzetét elemzem, összehasonlítva azt a korábbi vizsgálat során feltárt jellemzőkkel. Munkám második részében pedig azt vizsgálom, hogy az oktatási rendszer elmúlt bő egy évtizedének változásai hogyan hatottak az e térségekben élő fiatalok iskoláztatási és elhelyezkedési esélyeire.

Az elemzés időtávját közös tanulmányunk megjelenéséhez igazítottam. Mindkét időszakra jellemző sajátosság ugyanis, hogy a politikailag kényesnek tekinthető témakörök esetében (munkanélküliség, az oktatás minőségi jellemzői, az iskolai szegregáció) a hivatalos adatok „szépítik a valóságot”. Így akkor és ma is csak a hivatalos „adatok mögé nézve", közvetett információk alapján válik feltárhatóvá a valós helyzet.

A foglalkoztatással kapcsolatos elemzéseim hátterét különböző forrásból származó adatok mellett az elmúlt években több projekt keretében és több mintaterületen végzett empirikus kutatásaimra támaszkodnak.

Vizsgálataim egyértelmủen bizonyították, hogy a javulónak látszó hivatalos adatok ellenére az elmaradott vidéki térségekben élő hátrányos helyzetű, alacsony iskolai végzettségűek munkaerőpiacról történő végletes kiszorulásának veszélye 2002-höz képest napjainkra csak minimális mértékben oldódott. A hosszan tartó munkanélküliség, illetve az egyetlen legális jövedelmet jelentő időszakos közfoglalkoztatás továbbra is fenntartja az egyént, családot és közösségeket romboló függőségeket, perspektívátlanságot. E kilátástalan helyzetből történő kilépésre szinte az egyetlen valódi esélyt a tanulás, tudás biztosíthatja, így az oktatási rendszer által nyújtott szolgáltatások elérhetőségének és színvonalának kiemelkedő a jelentősége.

Elemzéseim bemutatják, hogy az elmúlt évek változásainak eredményeként Magyarországon a tanulói összetétel és az eredményesség szempontjából is egy nagyon erősen differenciálódó, markáns egyenlőtlenségeket rejtő általános iskolai intézményhálózat jött létre. Az egyenlőtlenségek térbeli szerkezete pedig szorosan követi a településhálózati jellemzőket, illetve a hátrányos helyzetű lakosság ezzel szoros összhangban lévő térbeli elhelyezkedését. A középiskolai képzés bő két évtizede zajló térbeli koncentrációs folyamatának egyértelmű nyertesei a nagyobb városok, fontosabb centrumtelepülések, tradicionális is-

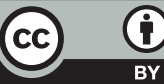


kolavárosok jó továbbtanulási eséllyel kecsegtető gimnáziumai, és a szintén e városokban lévő, infrastruktúrát, szakember-ellátottságot, eszközparkot és gazdasági kapcsolatokat tekintve is kedvező helyzetű szakképzések. Mindez a kollégiumi beilleszkedésre kevésbé alkalmas, a hosszú ingázást kevésbé vállaló, a magasabb színvonalú szolgáltatás iránt kevésbé érzékeny, többnyire hátrányos helyzetü családok gyermekeit érinti a legsúlyosabban. Így a kisvárosok lényegesen kisebb elhelyezkedési esélyt biztosító, leszakadó szakképzésébe visszaszorulók továbbviszik a családjukban immár évtizedek óta jellemzővé váló kilátástalanságot, perspektívátlanságot. Az állam által nyújtott középfokú oktatási szolgáltatások az esélyteremtés, esélykiegyenlítés helyett a területitársadalmi egyenlőtlenségeket (előnyöket és hátrányokat) újratermelő intézményrendszerként írhatók le.

Gábor VELKEY: research fellow, head of department, Great Plain Research Department, Institute for Regional Studies, Centre for Economic and Regional Studies; Szabó Dezső u. 42., H-5600 Békéscsaba, Hungary; velkey.gabor@krtk.mta.hu; http://orcid.org/0000-0002-4677-0743

KEYWORDS: vocational training system; socio-spatial inequalities; institutional and spatial selectivity; segregation; periphery; labour market position of young people

ABSTRACT: In the early 2000s, Éva G. Fekete and myself collaborated on the research project, which titled 'Tackling long-term unemployment in rural spaces' that introduced a novel approach within the field. In the first section of this paper, I analyse current labour market processes of backward rural spaces along the key dimensions we had identified in that project. In the following part, I focus on rearrangements of the education system that had transformative impact on the skills and labour market position of young people living in such spaces.

Thematically, this paper relies on the joint paper we had published together with Éva $G$. Fekete in 2002. This can be explained by the fact that public data related to politically sensitive issues (unemployment, quality of education services, institutional segregation, etc.) had to be scrutinized in both periods. Nowadays, like in the early 2000s, we must go beyond statistics and rely on informal information to understand real-world processes.

Analysis in this paper rests on public data about unemployment, such as labour market surveys of the Central Statistical Office and statistics on public works published by the Ministry of Interior. Data on education was obtained from KIRSTAT, reviews 'Indicators in public education' official databases of national competence surveys and series of field work done in the last few years.

The analysis suggests that the marginal labour market position of young people who have low education skills, come from low-income families and live in declining rural spaces has scarcely improved since 2002; they are still in danger of exclusion. Long-term unemployment and public work programs (a sole source for legal, though temporary income) reproduce destructive mechanisms such as personal dependencies, disintegration of communities, and life without perspectives. The only way to break this vicious circle is to advance personal skills, which can only be achieved by improving the quality of education services and by making them accessible to all.

Nevertheless, current institutional reforms entail a highly uneven system in primary education bifurcated by social structure and by student performance. Institutional inequalities reflect upon the hierarchical-administrative organisation of settlements and also on the spatial distribution of low income social groups. Centralisation processes of the last two decades favoured major urban centres with diverse education institutions (i.e. grammar schools) of high reputation and centres of vocational training with ample resources, such as infrastructure, business relations and skilled staff. Such processes marginalized those who cannot finance commuting, whose integration into broader communities is difficult, and for whom the quality of education is of less importance. As a consequence, students who are trapped in the institutions of small towns with low-quality training reproduce the social status of their parents, with no chance for upward mobility. Thus, public secondary education does not fulfil its mission on social equity, rather in its current form it is biased to reproduce socio-spatial inequalities. 


\section{Bevezetés}

G. Fekete Évával legelőször Szegeden, az egyetemi gólyatáborban találkoztam, végzős hallgatóként kalauzolt bennünket a matematika és földrajz tanszékeken. Legközelebb akkor futottuk ismét össze, amikor ő az MTA Regionális Kutatások Központja akkor létrehozott Miskolci Csoportjában kezdte el tudományos kutatói pályáját, én pedig friss diplomásként a Békéscsabai Kutatócsoportban helyezkedtem el. Kutatási területeink, érdeklődésünk ezután is sokszor hozott össze bennünket, mindketten foglalkoztunk az önkormányzati rendszer, a települési együttműködések és a helyi politika, helyi hatalom kérdésével. Vizsgálataink már ekkor is elsősorban a hátrányos helyzetű, periférikus, vidéki térségekre koncentráltak, ahol munkáinkban szinte kikerülhetetlenül került előtérbe a munkanélküliség és a foglalkoztatás strukturális és területi jellemzőinek kérdése.

E közös érdeklődés és megközelítés eredményeként született meg az a tanulmányunk, ami egy több éves kutatás összefoglalásaként a vidéki térségek tartós munkanélküliségének problémakörét és kezelésének lehetőségeit próbálta feltárni (G. Fekete, Velkey 2002). Maga a tanulmánykötet és a közösen írt zárótanulmány sok szempontból újszerủ megközelítéseket tartalmazott. Az én feladatom a vidéki munkanélküliség legfontosabb jellemzőinek minél részletesebb, adatokkal is alátámasztott feltárása volt, míg Éva a továbblépés, fejlesztés nemzetközi és hazai példákon alapuló lehetőségeit tekintette át. Munkáját ebben a kutatási projektben is egyszerre jellemezte a gyakorlatorientált megközelítés, vagyis annak igénye, hogy a kutatás eredménye alkalmas legyen a közvetlen beavatkozások, intézkedések megalapozására, valamint a tudományos alaposság, a háttérfolyamatok megértése, feltárása, kitérve minden fontos részletre, összetevőre.

Pályánk abból a szempontból is hasonlóan alakult, hogy mindkettőnket izgatott a kutatási eredmények gyakorlati hasznosításának kérdése; lehetséges-e, és ha igen, miként lehet kutatási tapasztalataink alapján közvetlenül is segíteni környezetünk, térségünk gondjain. ő a Csereháton a fejlesztéspolitikába vetette bele magát, én pedig Békéscsaba önkormányzatában próbáltam javítani a város és az itt élők helyzetén, fejleszteni a helyi közszolgáltatásokat, segíteni a közösségi, civil kezdeményezéseket, támogatni a társadalom részvételét saját lakókörnyezetének alakításában. Nálam ez a kutatástól való eltávolodást is magával hozta, így mindig csodáltam, hogy Éva milyen finoman találta meg az egyensúlyt a tudományos munka (kutatás, felsőoktatás) és a közéleti aktivitás között; egyszerre tudott az akadémiai rendszer megbecsült kutatójaként, tanszék-, majd intézetvezetőként és a vidéki elmaradott térségek napi gondokkal küzdő fejlesztőjeként is magas szinten helytállni.

A 2002-es közös kutatás után, megtartva az érdeklődés és megközelítés egybecsengő irányait, Éva a foglalkoztatási problémák kezelésében kikerülhetetlen helyi gazdaságfejlesztés kérdéskörébe ásta be magát, én pedig a foglalkoztatás szempontjából szintén meghatározó oktatási-képzési rendszer irányában folytattam 
előbb közéleti, majd kutatói tevékenységemet - továbbra is kiemelten figyelve a térbeli-társadalmi egyenlőtlenségekre. E munkáim során arra kerestem választ, hogy a gyorsan változó világgazdasági folyamatok, a magyarországi politikai és gazdasági válság - növekvő területi és társadalmi egyenlőtlenségekkel -, majd az állam szerepfelfogásában bekövetkező radikális váltás, illetve az e változó külső körülmények következtében formálódó helyi társadalmak, helyi közösségek miként alakították a hazai közfinanszírozott oktatás és szakképzés által biztosított lehetőségeket, különösen a periférikus térségek fiataljai számára. Legutolsó szakmai találkozásunkra az e témakörben a Miskolci Akadémiai Bizottság székházában általa szervezett vitaülésen került sor, ahol legfontosabb kutatási eredményeimet helyi kutatókkal, egyetemi oktatókkal és hallgatókkal vitattuk meg.

Jelen tanulmányom a szakképzés elmúlt bő két évtizedének változásait áttekintve azt vizsgálja, hogy az intézményrendszer térbeli koncentrációja, a fenntartói irányítás centralizációja, majd egységes állami felügyelet alá vonása, és a gazdasági szereplők befolyását növelő új gyakorlati képzési és finanszírozási rendszer hogyan hatott a térbeli-társadalmi egyenlőtlenségek újratermelésére, miként változott az elmaradott vidéki térségekben élő fiatalok iskoláztatási helyzete, foglalkoztatási esélye.

Az elemzés időtávját tudatosan igazítottam az Évával írt közös tanulmányunk megjelenéséhez, ugyanis érdekes párhuzamok jellemzik az elmaradott vidéki térségekben akkor és ma folytatott vizsgálatokat. Az elemzések módszertanát és a kutatási lehetőségeket is befolyásoló, mindkét időszakra jellemző sajátosság, hogy a politikai értelemben kényesnek tekinthető témakörök esetében - mint például a munkanélküliség, foglalkoztatás, vagy az oktatási rendszer minőségi jellemzői és az iskolai szegregáció - a hivatalos adatok „,szépítik a valóságot”. Így a valós helyzet akkor és ma is csak a hivatalos ,adatok mögé nézve”, közvetett információk, adatok alapján válik feltárhatóvá, megérthetővé.

A korábbi kutatás felelevenítése és aktualizálása arra is alkalmat ad, hogy mai elemzéseink legfontosabb kérdéseinek előzményeit keresve, a hosszabb távon ható összetevők segítségével értelmezzük napjaink jellemzőit.

\section{Elméleti megközelítés, módszerek}

Egyes térségek végletes leszakadása, a gazdasági, demográfiai és szociális problémák halmozódása, és az e folyamatokat erősító újabb jelenségek - az állam szerepében megfigyelhető módosulások (szűkülő állami szerepvállalás és erősödő centralizáció), a termelés rendkívül gyorsan változó térszerkezete, a társadalmi szolidaritással szembeni súlyos kihívást jelentő tömeges migráció és az erősödő polarizáció - a térbeli, társadalmi egyenlőtlenségek újratermelését a hazai és nemzetközi tudományos viták egyik legfontosabb kérdésévé tette (lásd Lang 2015; Nagy et al. 2015; Dunford, Liu 2016; Rodriguez-Pose 2018). Az elemzésekben 
új megközelítési irányként értelmezhető a folyamatok összetettségének, a gazdaságon túli tényezők szerepének hangsúlyozása, és a helyi, térségi sajátosságok figyelembe vétele (Soja 2010; Peck 2016). A társadalmi reprodukció mechanizmusainak és intézményi kereteinek feltárása egyes elemzésekben kiegészül a kedvezőtlennek, károsnak ítélt folyamatok megváltoztatására irányuló törekvésekkel is. Ilyenek például az erőforrások egyenlőbb elosztását, az alapvető szolgáltatásokhoz való kiegyenlített hozzáférést és a mobilitás (ingázás, migráció) feltételeinek széles körü biztosítását hangsúlyozó, a térbeli és társadalmi igazságosságra hivatkozó elemzések (Hajdimichalis, Hudson 2014; Sheppard 2018).

A tanulmányom fö kérdéskörét jelentő foglalkoztatás és közoktatás vonatkozásában mind a folyamatok komplexitásának hangsúlyozását, mind pedig a javak, szolgáltatások elérhetőségét (elosztás), és az azokhoz való hozzáférést meghatározó eljárások ,igazságosságát” fontos tartalmi kérdésnek tekintem. A foglalkoztatási problémákban, illetve az ezek kezelését célzó foglalkoztatáspolitikai, gazdaságfejlesztési kezdeményezésekben komplex módon jelennek meg a globális gazdasági folyamatok hatásai, az országos szinten szabályozott intézményi keretek és mechanizmusok (működtetés) következményei, és az ezek konkrét helyi megjelenését befolyásoló lokális társadalmi jellemzők, tradíciók, sajátosságok. A helyben tanulmányom esetében az elmaradott vidéki térségekben - megismerhető jelenségek vizsgálata teszi lehetővé e komplex hatások együttes értelmezését, hiszen a helyi társadalmi viszonyokon, adottságokon, örökségeken átszürve jelennek meg az azokon túlmutató hierarchiák, hálózatok hatásai. Ilyen hatás többek között az állami foglalkoztatáspolitika konkrét helyi (térségi) eszközrendszere és működési gyakorlata, másként fogalmazva azok a helyben elérhető konkrét ellátások, szolgáltatások, beavatkozások, melyek a foglalkoztatási problémák kezelését célozzák, és amelyek alapján elemezhető a területi és társadalmi igazságosság kérdése is.

Az oktatás-tanulás-képzés-nevelés rendszerének megszervezésében és müködtetésében az államnak a tankötelezettség bevezetésétől meghatározó szerepe van. E domináns szerepből értelemszerüen következik, hogy az oktatási rendszerek szervezésében a legfontosabb mechanizmus a bürokratikus koordináció és a közfinanszírozás. Ez attól függetlenül fennáll, hogy az egyes országok, országcsoportok eltérő társadalomfejlődés és intézményszervezési tradíciók után jutottak el a mai, az állami mellett valamilyen arányban egyházi, közösségi és magánszolgáltatásokat is lehetővé tevő, sokszínű oktatási rendszereikhez. E sokszínűség az állami és magánszolgáltatások aránya mellett elsősorban a decentralizáció mértékében, az önkormányzatok szerepében és felelősségében, az alap-, az egyéb szakmai és a kapcsolódó kiegészítő szolgáltatások meghatározásában és az intézményrendszer elkülönített szakaszaiban, területi szerkezetében jelenik meg, amit tovább differenciálnak a helyi tradíciók, sajátosságok, közöttük a különböző társadalmi csoportok lehetőségei érdekeik érvényesítésére (Velkey 2019a). Az állam azonban nemcsak közvetlenül az oktatási rendszeren keresztül, hanem közvetve is hatással van a szolgáltatás igénybevételére, hiszen a hozzáférést, elérhetőséget 
befolyásoló egyéb feltételek (úthálózat, tömegközlekedés, kollégiumi ellátás stb.) biztosításában is fontos szerepet tölt be.

Magyarországon a helyzetet tovább bonyolítják az elmúlt néhány évtizedben az állam szerepkörét, működtetését és feladatait, így az oktatási rendszert és az elérhetőséget is lényegesen megváltoztató, radikális politikai irányváltások. Az államszocializmus hierarchikusan felépített, mégis részben decentralizált „tanácsi" oktatási rendszerét 1990 után egy központi keretszabályozásra, önkormányzati fenntartásra és finanszírozási felelősségre, továbbá széles körü intézményi autonómiára alapozott, szélsőségesen decentralizált rendszer követett, majd 2011-től egy finanszírozásában, fenntartásában, irányításában és ellenőrzésében is egységesített, végletesen centralizált állami rendszer jött létre (Velkey 2013; Radó 2018). A vizsgált két évtizedben tehát lényegében minden olyan paraméter megváltozott, amelyek mentén az oktatási rendszerek leírhatók, így többek között az iskolahasználók, vagy a helyi társadalmak lehetőségei is e szélesen értelmezett rendszer alakítására.

Tanulmányom az elmaradott vidéki térségek foglalkoztatási viszonyait elemző korábbi kutatás másodelemzéséből kiindulva, foglalkoztatás- és oktatásstatisztikai adatokra és az elmúlt évtizedekben több kutatási projekt keretében végzett empirikus vizsgálataimra támaszkodik. A tanulmányomban többször hivatkozott kutatások az ország több térségében (Pásztó, Mezőkovácsháza, Sarkad és Sátoraljaújhely környékén) folytak, illetve (Békés, Heves és Komárom-Esztergom megyében) jelenleg is zajlanak, hátterét pedig az alap- és középfokú oktatás fenntartói, intézményi oldalának szereplőivel, a kapcsolódó gazdasági szervezetek, kamarák képviselőivel és az önkormányzati, közigazgatási szereplőkkel készített interjúk képezik.

A foglalkoztatással kapcsolatos elemzéseim hátterét a hivatalos munkanélküliségi statisztikák (a munkaügyi szervezet által gyüjtött regisztrált munkanélküliek, regisztrált álláskeresők és azok különböző szempontok szerinti megoszlása), a KSH Munkaerő-felmérés adatai, és napjaink folyamatainak elemzésekor a BM közfoglalkoztatási adatai adják. Ezen adatok párhuzamos elemzése teszi lehetővé a reális jellemzők, folyamatok árnyaltabb megértését, aminek hátterében a különböző adatgyűjtések módszeréből, jellegéből és az ezekkel (is) összefüggő korlátaikból következő, sokszor érdemi eltérések állnak. Az oktatási rendszerrel kapcsolatos elemzések legfontosabb hátterét a KIRSTAT adatok, illetve az ezeket bemutató és elemzo” „A közoktatás indikátorrendszere" című kiadványok, továbbá az Országos Kompetenciamérés országos és intézményi adatai képezik.

\section{Tartós munkanélküliek akkor és most - egy 2002-es kutatás mai szemmel}

A 2002-es vizsgálat egyik legfontosabb megállapítása az volt, hogy a munkanélküliek hazai nyilvántartási rendszere és a rendszeres adatgyűjtések nem tükrözik megbízhatóan, sőt inkább elfedik a tartós munkanélküliség valódi jelenségét. 
Azok a nyílt munkaerőpiacról tartósan kiszorulók, akik a vizsgált időszakban nem szerepeltek a munkanélküliségi statisztikákban, az akkori vizsgálatok szerint négy nagy csoportba voltak sorolhatók (G. Fekete, Velkey 2002):

(1) az elhelyezkedés valódi esélyét nem hordozó, ám a résztvevőket átmeneti ideig „rendezett státuszúvá” tevő, aktív foglalkoztatáspolitikai programok (közhasznú, közcélú munkavégzés, támogatott átképzési programok) résztvevői;

(2) a tartósan munka nélkül lévők segélyezési rendszerének (jövedelempótló támogatás) jellemzői miatt munkanélküli ellátásra és egyéb segélyre nem jogosultak, akik a munkaközvetítés kilátástalansága miatt „kikoptak" a regisztrációból;

(3) a háztartásba, szürkegazdaságba visszaszorulók, akik otthon, illetve alkalmi munkából jutottak valamilyen rendszeresnek tekinthető jövedelemhez;

(4) az elhelyezkedés esélyéről lemondó, egyéb járadékos státuszba (kisgyermekes támogatások, főállású anya/apa, ápolási segély, csökkent munkaképesség, korai nyugdíjazás) menekülők.

2002 körül így a hivatalos statisztikákban a munkanélküliségi ráta 10\% körül alakult, a tartós munkanélküliek aránya pedig a regisztrált munkanélküliek között a kilencvenes évek közepén jellemző 60\%-os értékről 30\% alá csökkent, ami nemzetközi összehasonlításban is kedvezőnek mondható. Ráadásul a munkaügyi szervezet által produkált hivatalos munkanélküliségi adatok alapján nem voltak elhatárolhatók „egymástól jól megkülönböztethető módon azok a területek, ahol a munkanélküliek között magas (volt) a tartósan munkanélküliek aránya" (Fekete 2002,68 .).

Mindezzel szemben a KSH Munkaerő-felmérés alapján a regisztrációba belépők között a nem pályakezdő első belépők radikálisan lecsökkenő aránya, valamint az ellátási jogosultságot szerzett nem első belépők dinamikusan növekvő aránya egyértelműen arra hívta fel a figyelmet, hogy a munkaügyi szervezet évek óta különösen a hátrányos helyzetủ térségekben - nagyrészt ugyanazt a tartósan munka nélkül lévő tömeget kezeli. A legrosszabb helyzetű megyékben (Baranya, Békés, Borsod-Abaúj-Zemplén, Heves, Jász-Nagykun-Szolnok, Nógrád, Szabolcs-SzatmárBereg) a nem pályakezdő első belépők aránya legfeljebb $2 \%$ volt. Vagyis a munkanélkülivé válók - figyelembe véve a megyék között lényegesen kisebb szóródást mutató $10 \%$ körüli pályakezdő arányt - közel 90\%-a korábban is volt már munkanélküli. Az ellátásra jogosultságot szerzett nem első belépők növekvő aránya (a sorolt megyék mindegyikében $60 \%$ körüli) arra hívta fel a figyelmet, hogy az aktív foglalkoztatáspolitikai eszközök nem képesek visszajuttatni a nyílt munkaerőpiacra a tartós munkanélküliek túlnyomó többségét. (Ami - ha ez a regisztrációban megjelenők esetében fennáll - hatványozottan igaz a passzívvá válókra.) A kimondottan alacsony aktivitási ráta (50\% alatti érték a sorolt megyék mindegyikében a 15-74 éves korosztályra vetítve) pedig egyértelmủen az egyéb járadékos státusz irányába menekülők magas arányára utalt. 
E közvetett adatok alapján fogalmazhattuk meg azt a súlyos megállapítást, miszerint ,a munkaügyi szervezetben nyilvántartott munkanélküliek legalább kétharmadát, a nem regisztrált munka nélkül lévőknek pedig a jelentős többségét fenyegeti a munkaerőpiacról történő tartós, illetve végleges kiszorulás". A közvetett adatokra támaszkodó elemzésünk kimutatta azt is, hogy a veszélyeztetettség a településhierarchia alján és a fejlődőképes központoktól távol, továbbá a szakképzettséggel nem rendelkezők esetében hatványozottan áll fenn (G. Fekete, Velkey 2002, 14.).

Az elmúlt néhány év hivatalos munkanélküliségi adatai szintén kedvezőnek nevezhetők, nemzetközi összehasonlításban is. 2015-ben a hivatalos munkaügyi statisztikák alapján mindösszesen 337448 nyilvántartott álláskereső volt az országban, a 15-64 éves népességhez viszonyított arányuk 4,95\% volt. A kedvezőbb helyzetű megyékben 1,4-4\%, a legrosszabb helyzetűekben 7-10\% között alakult az arányszám. A KSH Munkaerő-felmérés ekkor is kissé eltérő adatokat mutatva, 292700 munkanélkülit vett számba, akik közül 44\% több mint egy éve munka nélkül volt. Ráadásul a területi különbségek is élesebben jelentkeztek, a kedvezőbb helyzetű megyék 3-5, a legrosszabbak pedig 9-13\%-os rátát mutattak. A felmérés az inaktívak között további 42200 álláskeresési, vagy szociális ellátásban részesülőt és 66500 eltartott passzív munkanélkülit is számba vett, ami így mindösszesen 401400 munka nélkül lévő, 15-74 éves korosztályba tartozó személyt jelentett. Országos szinten az aktivitási ráta ekkorra már a 2002-es 52 és a 2010-es 55,2\%-kal szemben 58,6\%-ra emelkedett, ami valóban érdemi előrelépést jelent.

E kedvezőnek nevezhető adatok mögött a munkanélküliség állami kezelésének átalakítása állt, konkrétan az időben és volumenében radikálisan lecsökkent munkanélküliségi ellátás és a költségvetési forrásokból felfuttatott közfoglalkoztatási programok, melyek országos szinten ekkor 226600 föt érintettek. Ez utóbbiak a szakirodalom egybecsengő véleménye szerint is csak minimális arányban vezetnek vissza a nyílt munkaerőpiacra (Cseres-Gergely, Molnár 2015; Ferge 2017; Lipták 2020), vagyis lényegében a közösség érdekében végzett tevékenységért fizetett munkanélküli ellátást jelentenek.

A megyei szintig reprezentatív KSH Munkaerő-felmérés területi adatai lényegében ugyanazokat a területeket mutatták a magas munkanélküliség és a magas közfoglalkoztatási arány alapján is a legkedvezőtlenebb foglalkoztatási helyzetűnek (Czirfusz 2015), vagyis e térségekben lényegesen súlyosabb problémák voltak jellemzőek, mint amit az adatok külön-külön jeleztek (1-2. ábra).

A KSH Munkaerő-felmérés nem teszi lehetővé a részletesebb területi bontást, így járási szintű adatokat a munkaügyi szervezet által nyilvántartott álláskeresők és a közfoglalkoztatási programokban résztvevők adatai alapján elemezhetünk. E két csoport 15-64 éves korosztályra vetített együttes aránya a 2018-as adatok alapján még drámaibb területi különbségeket mutat (3. ábra). Figyelembe véve az érintettek iskolai végzettség szerinti megoszlását is, megállapítható, hogy a közvetett adatok lényegében ugyanazokat a területi és társadalmi egyenlőtlensé- 
1. ábra: Munkanélküliségi ráta a 15-74 éves népesség körében megyék szerint Unemployment rate within the population aged $15-74$ by counties

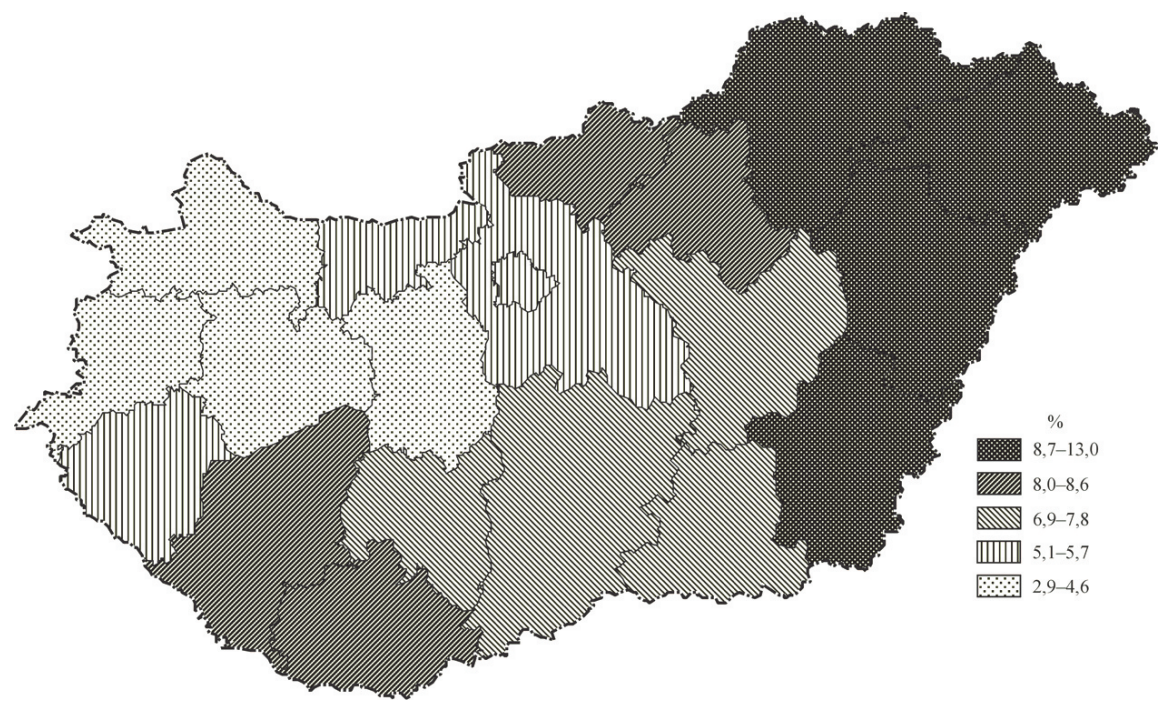

Forrás: TeIR, KSH Munkaerő-felmérés (2015)

2. ábra: A közfoglalkoztatottak aránya a 15-64 éves népesség körében megyék szerint Proportion of public employees within the population aged 15-64 by counties

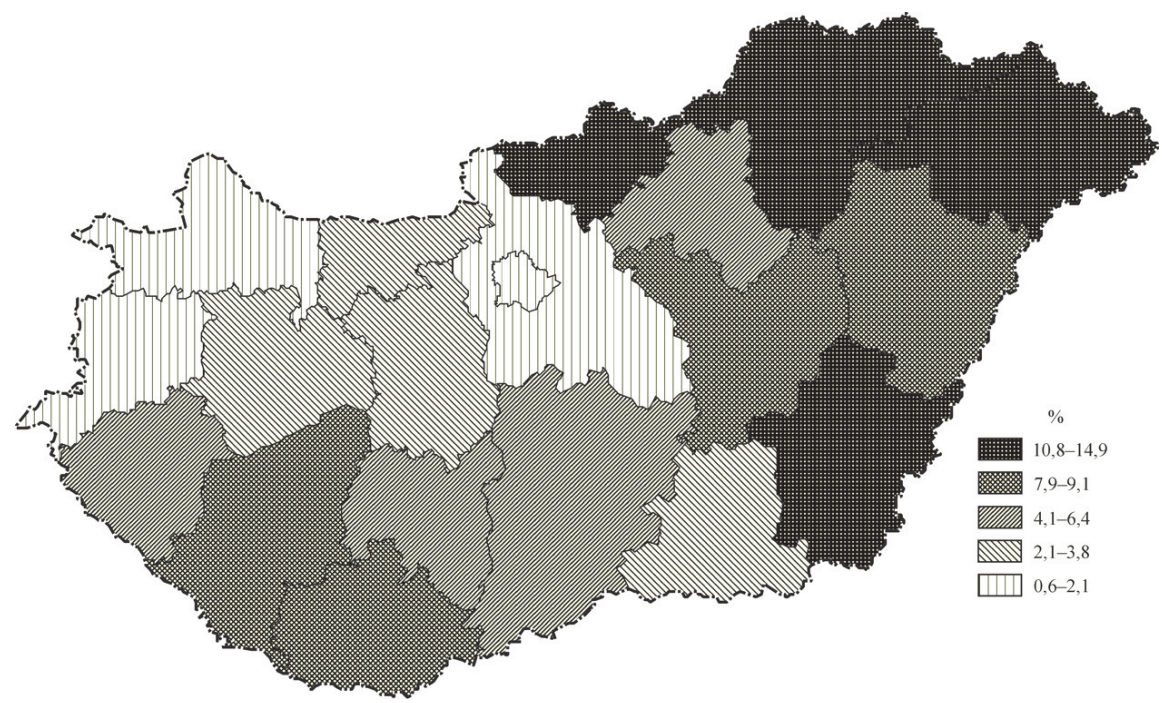

Forrás: TeIR, KSH-MRSTAR/BM-KF (2015) 
3. ábra: A munkanélküliek és közfoglalkoztatottak együttes aránya a

15-64 éves népesség arányában

The combined proportion of the unemployed and public works

employees within the population aged 15-64

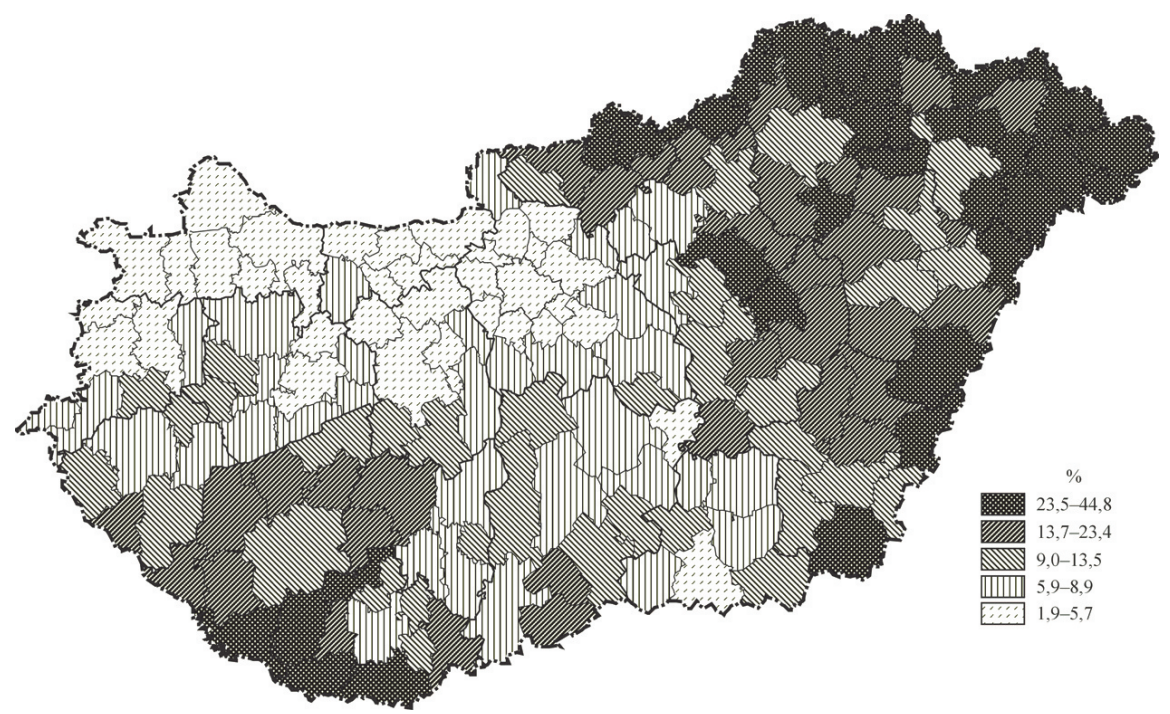

Forrás: TeIR, KSH-MRSTAR/BM-KF (2018)

geket tárják elénk, mint 2002-ben, mindössze azzal a nem elhanyagolható különbséggel, hogy a kedvezőbb és kedvezőtlenebb térségek közötti különbségek tovább nőttek (3. ábra). A nyugati és központi országrész, továbbá a nagyvárosok és közvetlen környezetük járásainak 2-6\%-os munkanélküli és közfoglalkoztatási (együttes) arányával szemben a fejlődőképes központoktól távolabb fekvő (határ menti térségek és belső perifériák), legrosszabb helyzetű járások 25-45\%-os arányt mutatnak az aktív (15-64 éves) korúak körében, ami a 2002-ben megfigyelhető polarizáció legalább másfél-kétszeres növekedésére utal.

Mindennek következtében ma is megismételhetők, továbbra is érvényesek a 2002-ben lezárt kutatás legfontosabb megállapításai:

- A nyílt munkaerőpiacról történő tartós kiszorulás „nem csupán a munkanélküliség egy hosszabb időtartamra szóló változata, hanem minőségileg is más kategória". Társadalmi veszélyessége a kiváltott negatív hatások egymást erősítő, „lefelé futó spirális szerveződése” miatt különösen erős, hatásai a mikroközösség egészét érintik, megváltoztatva életformájukat, szemléletüket, értékrendjüket, jelenhez és jövőhöz való viszonyukat, egymáshoz és a környezetükhöz füződő hozzáállásukat.

- A munkanélküliek hazai nyilvántartási rendszere és a rendszeres adatgyüjtések nem tükrözik megbízhatóan, inkább elfedik a tartós munkanélküliség valódi jelenségét, így annak lényege és jellemzői közvetett információk alapján tárhatók fel. 
- Jól körülírható társadalomszerkezeti és területi, településszerkezeti sajátosságok növelik a munkaerőpiacról történő tartós kiszorulás kockázatát. Az alacsony iskolai végzettségűek, a nők, a közszolgáltatások elérhetősége és színvonala miatt kedvezőtlenebb helyzetű kisebb településeken, és a fejlődést magukban hordozó központoktól távolabb eső, periférikus térségekben élők a leginkább veszélyeztetettebb csoportok (G. Fekete, Velkey 2002, 4.).

- E hátrányokat tovább erősítik és differenciálják az származással, életkorral és a családban élő gyermekek magasabb számával kapcsolatos előítéletek (Szarvák 2002; Balcsók 2002).

A hosszan tartó munkanélküliség, illetve az egyetlen legális jövedelmet jelentő időszakos közfoglalkoztatás - a kétség nélkül kimutatható pozitív hatások mellett - továbbra is fenntartja az egyént, családot és közösségeket romboló függőséget, perspektívátlanságot (G. Fekete 2015). Vizsgálatunk szempontjából azonban a következő generációkra gyakorolt hatások az igazán érdekesek. A kiszámíthatatlan, tervezhetetlen jövő alapvetően befolyásolja a fiatalok értékrendjét, életszemléletét, munkához, közösséghez való viszonyát. Ilyen körülmények között különös jelentősége van az oktatás-képzés elérhető intézményrendszerének és az általa nyújtott szolgáltatások színvonalának, amely szinte az egyetlen valódi esély a tanulás, tudás és az arra alapozott mobilitás révén e kilátástalan helyzetből történő kilépésre. A magasabb szintű kognitív készségek ugyanis kimutathatóan csökkentik a munkanélküliség valószínűségét, illetve növelik a magasabb keresetek elérésének esélyét. És bár a kognitív készségek alakulásában szerepet játszanak a családi környezet, a kortárscsoport összetétele, az egészségi állapot és más társadalmi hatások is, az oktatás minőségének ezeknél jól dokumentálhatóan fontosabb szerepe van (Hermann et al. 2018).

\section{A hazai oktatási-képzési rendszer legfontosabb jellemzői és szerepe az egyenlőtlenségek újratermelésében}

A társadalmi-térbeli egyenlőtlenségek és azok újratermelése az oktatási rendszer esetében az előrehaladási esélyek alakulásában ragadhatók meg. Abban, hogy az érintettek számára lakóhelyüktől, jövedelmi helyzetüktől, családi hátterüktől, származásuktól, kapcsolatrendszerüktől függetlenül, képességeik, adottságaik alapján biztosított-e a lehetőség magas szintű teljesítmény eléréséhez.

A tanulók szervezett keretek között iskolákban, azon belül pedig tanulócsoportokban veszik igénybe az oktatási szolgáltatásokat. Szinte minden oktatási rendszer valamilyen életkorban intézményváltásra kényszeríti a tanulókat, különböző továbblépési irányokat kínálva fel számukra. Az országok többségében azonban ez a szelekció nem 14 éves korban (vagy azt megelőzően, mint a hat és nyolc évfolyamos gimnáziumoknál), hanem később, és nem egy, hanem több lépésben 
történik. Sőt többnyire biztosított a hibás választás korrekciójának lehetősége is. Magyarországon az intézményváltás, a középiskolába történő belépés (14 éves korra) minden tanuló esetében bekövetkezik. És bár az átjárhatóságra hivatkozva voltak kezdeményezések arra, hogy a képzés szintjében és a szakmai kimenetelben lehetőség legyen a választás korrekciójára, a szakirodalomban nincs vita arról, hogy a magyar rendszer túl korán, nehezen megváltoztathatóan és kellő megalapozottság nélkül kényszeríti ki a tanulók intézményváltását (lényegében pályaválasztását). Amiből értelemszerűen következik, hogy a középiskolai továbbtanulásban az alapfokon mutatott iskolai teljesítménynek (tanulmányi eredmény) van döntő szerepe (Hermann 2008; Csapó 2008; Velkey 2013).

Vagyis a tanulók teljesítményében megfigyelhető egyenlőtlenségek az alapfokú képzési rendszerben alapozódnak meg, majd ezeket erősíti tovább a közismereti képzés színvonalában hatalmas különbségeket mutató középfokú intézményrendszer. A középfokú iskolatípus tanulói teljesítményeket befolyásoló hatását elemző kutatások szerint az általános iskolában hasonló teljesítményt nyúitó diákok a 10. évfolyamos kompetenciamérés alapján a szakközépiskolákban 50-60 ponttal alacsonyabb eredményt értek el matematikából és szövegértésből, mint a szakgimnáziumokban, a gimnazisták eredményei pedig hozzájuk képest is 20-25 pontnyi előnyt mutattak (Hermann 2018). A 2015-ös PISA-mérés eredményei szerint pedig az iskolák közötti különbségek magyarázó ereje a természettudományi eredmények szórásában Magyarország esetében nemzetközi összevetésben is kiemelkedően magas (Radó 2018).

Így abban, hogy milyen pályát futhat be egy periférikus térség hátrányos helyzetű családjának jó képességű gyermeke, két tényezőnek van meghatározó szerepe: az elérhető szolgáltatásoknak és azok színvonalának (az általános iskolai és a középiskolai képzés esetében is), illetve a tanulók iskolák közötti elosztását (továbbtanulás) meghatározó szelekciós mechanizmusoknak. Másként fogalmazva tehát annak, hogy a tanulók milyen színvonalú oktatást kapnak az általános iskolában, illetve hányadik évfolyam után, és milyen típusú és színvonalú középfokú oktatási intézményben tanulnak tovább.

A következőkben szorosan e két tényezőre (elérhetőség, szelekciós mechanizmusok) koncentrálva tekintem át a hazai oktatási-képzési rendszer legfontosabb változásainak hatását a periférikus térségek hátrányos helyzetű fiataljainak iskoláztatási, foglalkoztatási esélyeire.

\section{Az általános iskolák gyorsuló minőségi differenciálódása és következményei}

Az általános iskolák gyorsuló minőségi differenciálódása, és az azzal párhuzamosan egyre erőteljesebben, és egyre szélesebb körben megjelenő szelekció és szegregáció a hazai szakirodalom által részletesen elemzett és dokumentált folyamat. Ebben a kétezres évek első évtizedének végéig a nagyobb városok gyermekelszívó hatásának, az elitiskolák térnyerésének, a roma népesség arányának, a települé- 
seken belüli társadalmi elkülönülésnek és az előitéletek alakulásának egyaránt fontos szerepet tulajdoníthatunk (Havas 2008; Kertesi, Kézdi 2009; Fejes, Szűcs 2018). A jelenség hátterében a fenntartók pénzügyi helyzetében (oktatásfinanszírozási lehetőségeiben) megfigyelhető erőteljes polarizálódás, és a helyi elit érdekeit kiszolgáló önkormányzati döntések érzékelhetők (Zolnay 2018; Velkey 2019a). Ezek együtt határozzák meg azokat a legfontosabb feltételeket, amelyek keresetté, népszerűvé tehetik az intézményeket, és biztosítják a tanulók közötti válogatás lehetőségét is (infrastruktúra állapota, felszereltség, fejlesztési lehetöségek, humán erőforrások, tagozatok, művészeti, nyelvi képzések, tehetséggondozás, felzárkóztatás, fejlesztő foglalkozások, sport stb.).

A kétezres évek elején elfogadott deszegregációs szabályok és a társulásban ellátott feladatok arányának növekedése mérsékelte a folyamatok ütemét, a kedvezőtlen tendenciát azonban nem változtatta meg: a magasabb státuszú családokat a jobb pénzügyi helyzetben lévő, társadalmi összetételüket és a továbbtanulás esélyeit tekintve kedvezőbb (központi, városi, egyházi) iskolák választása felé tolta (Imre 2005; Pusztai 2009). E folyamat jól nyomon követhető a bejáró tanulók arányának növekedésében és a települések nagysága alapján érdemi különbségeket mutató Országos kompetenciamérések eredményeiben (Hajdú et al. 2019; Belinszki et al. 2019).

A 2010 utáni új oktatási rendszer az intézmények közvetlen állami fenntartásba és központosított irányítás alá vonásával látszólag kezelte az önkormányzati fenntartásból, a települések erősen differenciált pénzügyi helyzetéből és a fejkvótaalapú finanszírozásból következő problémákat. A kisebb települési iskolák forráshiánya valóban oldódott, ám a korábban jobb helyzetű városi és nagyvárosi iskolák finanszírozási háttere kimutathatóan romlott. Az új állami oktatáspolitika nyíltan preferált intézményei az egyházi iskolák lettek. Ez az állami iskolák forrásait érdemben meghaladó költségvetési támogatásban, a lényegesen nagyobb mozgástérben, a kiegészítő szolgáltatások lehetőségében és a helyi döntési szabadságban jelent meg. Az egyházi iskolák száma 2006-2016 között országosan több mint kétszeresére nőtt, részarányuk az általános iskoláknál napjainkban 15\% körül alakul. A válogatás „szabadságával” rendelkező iskolák számának növekedése pedig még tágabbra nyitotta a társadalmi helyzet, etnikai háttér alapján történő szelekció lehetőségét.

A szolgáltatások államosításának folyamatában a kiegészítő szolgáltatások (pedagógiai szakszolgálatok, szakmai szolgáltatások, szociális jellegű kiegészítő feladatok stb.) korábbi rendszerei szétestek, majd az egyes intézményegységek (intézmények, telephelyek) szintjén csupán a szociális jellegűek (egész napos ellátás, iskolai étkeztetés, iskolaorvos) feltételrendszerét teremtették meg. A gyermekjóléti szolgáltatások továbbra is az önkormányzatok feladatát képezik, az állami ellátás keretei között megszervezett gyógytestnevelés, gyógypedagógiai ellátás, korai diagnosztizálás és fejlesztés pedig még a városokban is visszaszorult. Míg a korábbi finanszírozási rendszer az ellátási szükségletek feltárásában és kezelésében tette érdekeltté a szereplőket, az új csupán a legszük- 
ségesebb személyzet bérkeretének biztosítását írja elő (Velkey 2019b). Noha 2013 után a hivatalos statisztikákban a hátrányos helyzetű és a halmozottan hátrányos helyzetű tanulók számának csökkenése figyelhető meg (Hajdú et al. 2019), ez azonban nem a valós folyamatok, hanem a besorolás jogszabályi változásának eredménye (Ferge 2017).

A tanárok kötelező óraszámának növekedése, a tartalmi előírások merevvé válása, az önálló kezdeményezések korlátozása, a túlmunka ellentételezésének megszűnése és a kiegészítő személyzet (pedagógiai asszisztens, mentálhigiénés, informatikai segítők stb.) továbbra is jellemző hiánya a minőségi pedagógiai munkát nagyban nehezítve, tovább növelték az ún. szeparációs nyomást (Radó 2018). Az iskolák eszközök és segítő szakemberek nélkül partnerré váltak a homogén csoportok szervezésében, a problémát jelentő diákok elkerülésében, vagyis tudomásul veszik, esetleg támogatják (is) a szelekciót és a szegregációt.

Mindez együttesen a tanulói összetétel és az eredményesség szempontjából erősen differenciálódó, markáns egyenlőtlenségeket rejtő intézményhálózatot eredményezett, mely egyenlőtlenségek térbeli szerkezete szorosan követi a településhálózati jellemzőket, illetve a hátrányos helyzetű lakosság ezzel szorosan összefüggő térbeli elhelyezkedését. Az országos kompetenciamérés hatodik osztályban szövegértésben mért járási átlagadatai arra hívják fel a figyelmet, hogy a fiatalok jó középiskolába történő bekerülésének esélye szoros összefüggésben van településük térbeli elhelyezkedésével, hierarchiaszintjével és az ott elérhető oktatás színvonalával (4. ábra). A hát-

4. ábra: Az országos kompetenciamérés hatodik osztályban mért átlageredményei szövegértésből a járások szintjén Average results of text comprehension in the sixth grade at the district level in the national competency survey

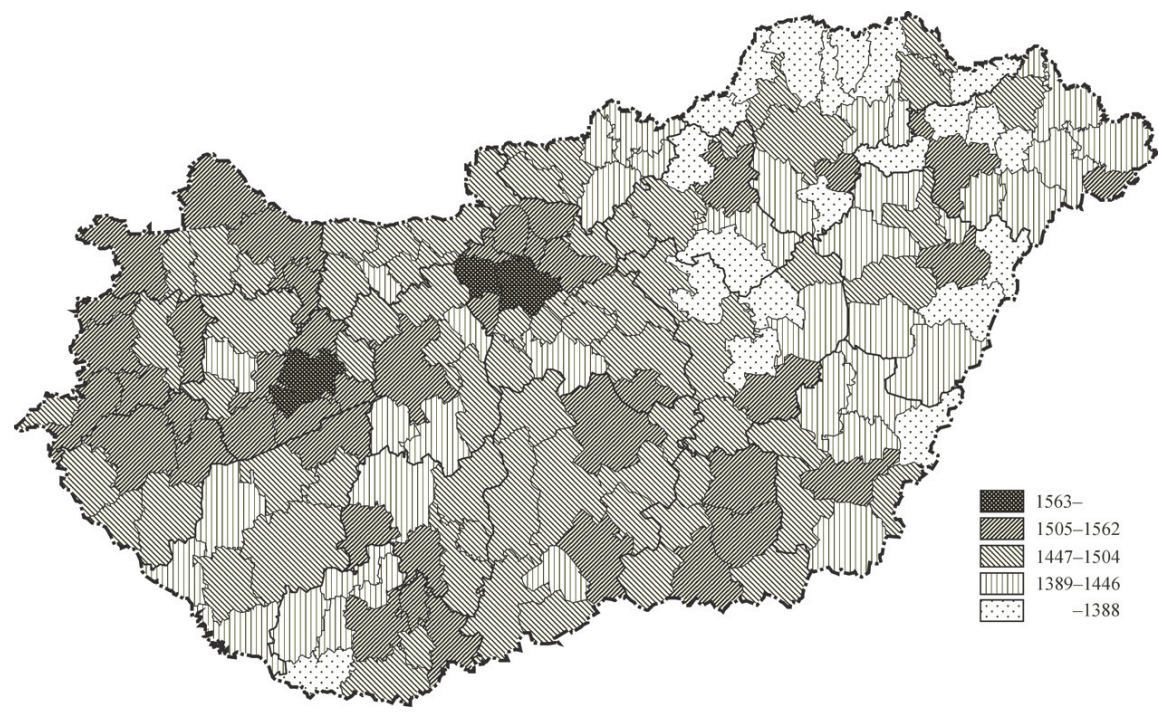

Forrás: Országos kompetenciamérés 2019, Országos jelentés 7. táblázat 
rányos és a nagyobb városoktól távoli térségekben élő fiatalok túlnyomó többsége számára a középiskolai továbbtanulás egyetlen elérhető iránya a szakközépiskolai (korábbi elnevezése szerint a szakiskolai) képzés marad.

\section{A középiskolai képzés térszerkezetének változásai és hatása a hátrányos helyzetü térségekben élók szolgáltatásokhoz való hozzáférésre}

A középfokú oktatásban a kilencvenes évek első felében a gyermeklétszám csökkenése ellenére gyorsan bővülő képzési kapacitások alakultak ki Magyarországon. A bővülés elsősorban az érettségit adó képzéseket, azon belül pedig a gimnáziumi képzést jellemezte. Ennek egyik oka a nyolcosztályos gimnáziumi hagyományok újjáéledése, amit a gyermekekért folyó verseny erősödése miatt az önkormányzati iskolák körében is egyre jellemzőbbé váló, a rendhagyó szerkezetü hat- és nyolcosztályos gimnáziumok számának növekedése követett (Velkey 2013). Az 1990-es évek első felének másik lényeges változása a vegyes (többcélú) oktatási intézmények elterjedése. Az iskolák az élesedő versenyre reagálva munkaerőpiaci igénnyel és gazdasági kapcsolattal nem alátámasztott divatos, vagy azzá tehető képzéseket kezdtek indítani, az érettségit adó és a felsőoktatás-orientált képzések népszerüségének érzékelhető növekedése miatt a szakiskolák szakközépiskolai, a szakközépiskolák pedig gimnáziumi osztályokat szerveztek. A képzési kínálat bővülésével párhuzamosan megfigyelhető volt egy gyorsuló minőségi differenciálódás is, ami a középfokú képzési rendszer térbeli koncentrálódását indította el. A korábban virágzó kis- és középvárosi középfokú oktatás fokozatos leépülését a nagyobb városok és megyeszékhelyek bővülő középfokú oktatási kínálata, továbbá a pénzügyi forrásokban, a szakember-ellátottságban, az infrastruktúra állapotában és a szakképzésben lényeges gazdasági kapcsolatokban megjelenő versenyhátrányok magyarázzák. A centrumtelepülések és a nagy tradíciójú iskolavárosok divatos középiskolái szinte minden képzési irány és szint esetében beszívták a jobb képességű, kedvezőbb társadalmi helyzetű, továbbtanulás-orientált tanulókat. A kollégiumban lakó és a bejáró tanulók arányainak e településeken megfigyelhető folyamatos növekedése az adatok szintjén is jól dokumentálja ezt a folyamatot. A differenciáltan bővülő képzési kapacitások másik fontos következménye az érettségit adó képzések elszívó hatása, ami már a kétezres évek legelejétől a szakiskolai képzések keresettségének lényeges csökkenését eredményezte (Velkey 2019b).

A hazai szakképzési rendszer modernizálására tett kísérletként értelmezhető a Térségi Integrált Szakképző Központok (TISZK) rendszerének bevezetése, amely további iskola- és térszerkezeti változásokat eredményezett. A program elsősorban a képzés tartalmának és a szakképzést segítö infrastruktúrának a megújítását, fejlesztését célozta, ám egyúttal a fejlesztési források hatékonyabb felhasználására hivatkozva, a szétaprózott szakképzési intézményrendszer nagyobb egységekbe szervezését is elő kívánta segíteni. Legfontosabb következménye, hogy több nagy 
szervezeti egységbe vonta össze a korábban önálló szakképző intézményeket, ami egyrészt az irányítás centralizációját eredményezve a kis- és középvárosi szakképző bázisok szerepének háttérbe szorulását vonta maga után, másrészt pedig tovább erősítette a térbeli koncentrációt (Martonfi 2009; Velkey 2011).

Az oktatás hazai rendszerének radikális átalakítását célul kitűző, 2011 végén elfogadott új jogszabálycsomag az intézmények még nagyobb egységekbe történő összevonását írta elő, a szakképzésben pedig visszaállította a közismereti és szakképzési tartalmak párhuzamos szervezését. Ez egyrészt véglegesítette a tizennégy éves korban történő pályaválasztást, másrészt előbb aránytalanul megnövelte a szakgimnáziumokban tanulók leterheltségét, majd a közismereti tartalmak csökkentésével korlátozta a felsőoktatási továbbtanulás esélyét. Az általános konvertálható tudástartalmak arányának szakközépiskolákban jellemző még nagyobb arányú csökkenése magyarázza az Országos kompetenciamérés középiskolai programtípusokhoz kapcsolódó fentebb hivatkozott növekvő különbségeit (Hermann 2018).

A döntéshozók szándékaival ellentétben mindez a szakgimnáziumok és általában a szakképzés keresettségének további kimutatható csökkenését eredményezte, a gimnáziumban tanulók részaránya 2002 és 2011, illetve 2011 és 2018 között is növekedett (Hermann, Varga 2018; Hajdú et al. 2019). E változások azonban csak minimális mértékben változtatták meg az egyes képzési típusok járási szintű elérhetőségét. Miközben a gimnázium nélküli járások száma az elmúlt néhány évben kismértékben növekedett (11-ről 15-re), a szakközépiskoláknál ellentétes irányú folyamat látható, a képzés nélküli járások száma a 2007-es 18-ról napjainkra 14-re csökkent. A szakgimnáziumok esetében a 2006-2009 közötti kisebb növekedést gyors visszarendeződés, majd újabb növekedés követte, jelenleg 17 járásban nem érhető el e szolgáltatás (Hajdú et al. 2019). A fentebb részletesen bemutatott térbeli koncentrációs folyamatokat is figyelembe véve mindez azt jelenti, hogy bár öt járást leszámítva, valamilyen középfokú oktatás mindenhol elérhető, ennek ellenére a tanulók egyre nagyobb aránya választja a nagyobb városok, fontosabb centrumtelepülések, tradicionális iskolavárosok magasabb színvonalú képzéseit. Ez a minőségi szolgáltatás folyamatosan erősödő térbeli koncentrálódását jelentő folyamat az e városoktól távolabbi térségekben élőket, azon belül pedig a kollégiumi beilleszkedésre kevésbé alkalmas, a napi ingázás nehézségeit kevésbé vállaló, a magasabb színvonalú szolgáltatás iránt kevésbé érzékeny hátrányos helyzetű családok gyermekeit érinti a legsúlyosabban, akik így visszaszorulnak a kisvárosok romló szolgáltatást és lényegesen kisebb továbbtanulási, elhelyezkedési esélyt kínáló középiskoláiba, főképp szakközépiskoláiba.

A tankötelezettség tizenhat éves korra történő leszállítása pedig tovább növelte a közoktatásból lemorzsolódók számát és arányát, aminek hatására kis mértékben ugyan emelkedett a 17 éves korban foglalkoztatottak száma, ám ennél lényegesen nagyobb arányban nőtt a munkanélküliek, közfoglalkoztatottak és nem tanuló eltartottak száma (Molnár 2018). Területi megoszlásuk pedig a leg- 
5. ábra: Az országos kompetenciamérés tizedik osztályban mért átlageredményei szövegértésből a járások szintjén Average results of text comprehension in the tenth grade at the district level in the national competency survey

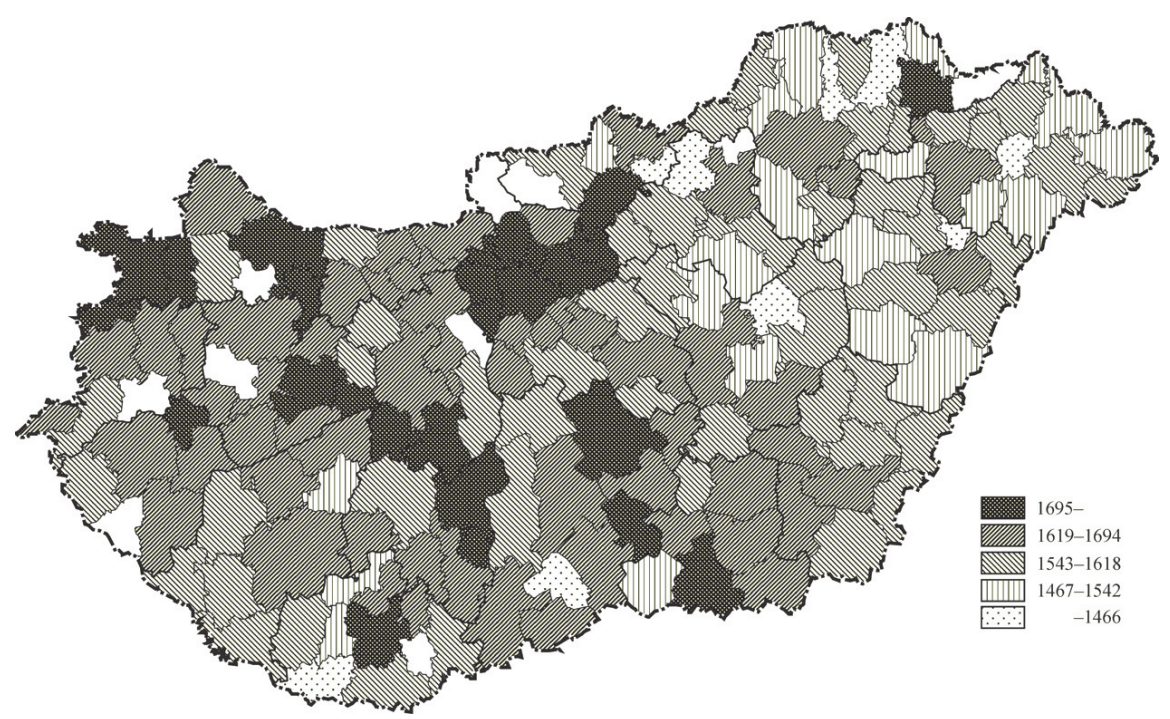

Forrás: Országos kompetenciamérés 2019, Országos jelentés 7. táblázat

hátrányosabb, romák által magasabb arányban lakott térségekben mutatja a legrosszabb adatokat (Köllő, Sebők 2018).

A periférikus térségek hátrányos helyzetű lakosságát halmozottan sújtó változások következményeit komplex módon foglalják össze, dokumentálják az Országos kompetenciamérés 10. évfolyamon szövegértésből mért járási átlagpontszámainak súlyos területi egyenlőtlenségeket elénk táró adatai (5. ábra). Az ötödik térkép országos szinten ugyanazokat a térségeket mutatja kedvezőnek és súlyosan leszakadónak, mint harmadik, amely napjaink foglalkoztatási egyenlőtlenségeit mutatja be.

\section{Rövid összefoglalás}

A javulónak látszó hivatalos adatok ellenére közvetett információk alapján egyértelműen megállapítható, hogy az elmaradott vidéki térségekben élő hátrányos helyzetü, alacsony iskolai végzettségű emberek munkaerőpiacról történő végletes kiszorulásának veszélye 2002-höz képest napjainkra csak minimális mértékben oldódott. A hosszan tartó munkanélküliség, illetve az egyetlen legális jövedelmet jelentő időszakos közfoglalkoztatás - a kétség nélkül kimutatható pozitív hatások mellett - továbbra is fenntartja az egyént, családot és közösségeket romboló függőségeket, perspektívátlanságot. Ilyen körülmények között e kilátás- 
talan helyzetből történő kilépésre szinte az egyetlen valódi esélyt a tanulás, tudás és az arra alapozott mobilitás biztosítja, vagyis a következő generációk szempontjából hatalmas jelentősége van az oktatási rendszer által nyújtott szolgáltatások elérhetőségének és színvonalának.

A társadalmi-térbeli egyenlőtlenségek és azok újratermelése az oktatási rendszer esetében az előrehaladási esélyek alakulásában ragadhatók meg. Abban, hogy az érintettek számára lakóhelyüktől, jövedelmi helyzetüktől, családi hátterüktől, származásuktól, kapcsolatrendszerüktől függetlenül biztosított-e a lehetőség képességeik, adottságaik alapján magas szintű teljesítmény eléréséhez.

A magyar rendszer azonban túl korán, nehezen megváltoztathatóan és kellő megalapozottság nélkül kényszeríti ki a tanulók intézményváltását, amiből az is következik, hogy a középiskolai továbbtanulásban az alapfokon mutatott iskolai eredménynek van meghatározó szerepe. Így abban, hogy milyen pályát futhat be egy periférikus térség hátrányos helyzetű családjának jó képességű gyermeke, a legnagyobb szerepe az általános iskola színvonalának van, majd annak, hogy az itt elért eredmény alapján milyen középiskolába képes bekerülni.

Az elmúlt évek változásainak eredményeként Magyarországon a tanulói összetétel és az eredményesség szempontjából is egy nagyon erősen differenciálódó, markáns egyenlőtlenségeket rejtő általános iskolai intézményhálózat jött létre. Az egyenlőtlenségek térbeli szerkezete pedig szorosan követi a településhálózati jellemzőket, illetve a hátrányos helyzetű lakosság ezzel szoros összhangban lévő térbeli elhelyezkedését. Az elmaradott térségekben és a nagyobb városoktól távolabb élő, hátrányos családi helyzetből induló fiatalok túlnyomó többsége számára tanulmányi eredményük alapján a középiskolai továbbtanulás elérhető szintje a szakközépiskola (korábbi elnevezése szerint a szakiskola) marad.

A középiskolai képzés bő két évtizede zajló térbeli koncentrációs folyamatának egyértelmű nyertesei a nagyobb városok, fontosabb centrumtelepülések, hagyományos iskolavárosok jó továbbtanulási eséllyel kecsegtető gimnáziumai, illetve az itt elérheto", infrastruktúrát, szakember-ellátottságot, eszközparkot és gazdasági kapcsolatokat tekintve is lényegesen kedvezőbb helyzetű szakgimnáziumi és szakközépiskolai képzések. Ez a minőségi szolgáltatás gyorsuló térbeli koncentrálódását is eredményező folyamata az e városoktól távolabb élőket, azon belül pedig a kollégiumi beilleszkedésre kevésbé alkalmas, hosszú ingázást kevésbé vállaló, magasabb színvonalú szolgáltatás iránt nem igazán érzékeny, többnyire hátrányos helyzetü családok gyermekeit érinti a legsúlyosabban. A kisvárosok szakképzésébe visszaszorulók pedig a lényegesen kisebb elhelyezkedési esélyt biztosító képzésekben részesülve viszik tovább a családjukban immár évtizedek óta jellemzővé váló kilátástalanságot, perspektívátlanságot.

Összefoglalóan elmondható tehát, hogy az állam által nyújtott középfokú oktatási szolgáltatások az esélyteremtés és esélykiegyenlítés helyett a területitársadalmi egyenlőtlenségeket (előnyöket, hátrányokat) újratermelő intézményrendszerként írhatók le. 


\section{Köszönetnyilvánítás}

A tanulmányt megalapozó kutatások az NKFI_(OTKA)-6-K-125110 „A szakképzés munkapiaci illeszkedésének területi és ágazati jellemzői, kiemelt figyelemmel a periférikus térségekre és a korai iskolaelhagyás problémájára" című kutatás (2017-2021) keretében folytak.

\section{Irodalom}

Balcsók I. (2002): A tartósan munkanélkülivé váltak esélyei Szatmár szívében. In: G. Fekete É. (szerk.): A tartós munkanélküliség kezelése vidéki térségekben. MTA RKK Vidékfejlesztési Mühely, Miskolc, Pécs, 246-261.

Belinszki B., Szepesi I., Takácsné Kárász J., Vadász Cs. (2019): Országos kompetenciamérés 2019 - Országos jelentés. Emberi Erőforrások Minisztériuma, Oktatási Hivatal, Köznevelési Mérés Értékelési Osztály https://www.oktatas.hu/pub_bin/dload/kozoktatas/meresek/orszmer2019/Orszagos_jelentes_2019.pdf (Letöltés: 2020.08.25.)

Csapó B. (2008): A magyar iskolarendszer adaptációs problémái. A tudás minősége. In: Fazekas K. (szerk.): Közoktatás, iskolai tudás és munkapiaci siker. MTA Közgazdaságtudományi Intézet, Budapest, 113-130.

Cseres-Gergely Zs., Molnár Gy. (2015): Munkapiaci helyzet a közfoglalkoztatásból való kilépés után. In: Fazekas K., Varga J. (szerk.): Munkaerőpiaci Tükör 2014. MTA Közgazdaság- és Regionális Tudományi Kutatóközpont, Közgazdaság-tudományi Intézet, Budapest, 143-153.

Czirfusz M. (2015): A közfoglalkoztatás térbeli egyenlőtlenségei. In: Fazekas K., Varga J. (szerk.): Munkaerőpiaci Tükör 2014. MTA Közgazdaság- és Regionális Tudományi Kutatóközpont Közgazdaság-tudományi Intézet, Budapest, 126-138.

Dunford, M., Liu, W. (2016): Uneven and Combined Development. Regional Studies, 1., 69-85. https:// doi.org/10.1080/00343404.2016.1262946

Fejes J. B., Szűcs N. (szerk.) (2018): Én vétkem. Helyzetkép az oktatási szegregációról. Motiváció Oktatási Egyesület, Szeged

Fekete A. (2002): A tartós munkanélküliség alakulása a 90’-es évtizedben. In: G. Fekete É. (szerk.): A tartós munkanélküliség kezelése vidéki térségekben. MTA RKK Vidékfejlesztési Műhely, Miskolc, Pécs, 61-94.

Ferge Zs. (2017): Magyar társadalom- és szociálpolitika (1990-2015). Osiris Kiadó, Budapest

G. Fekete É., Velkey G. (2002): Tartós munkanélküliség és kezelése vidéki térségekben - kutatási zárótanulmány. In: G. Fekete É. (szerk.): A tartós munkanélküliség kezelése vidéki térségekben. MTA RKK Vidékfejlesztési Mühely, Miskolc, Pécs, 9-60.

G. Fekete É. (2015): A vidéki munkanélküliség tömegessé válásától az új foglalkoztatási modellekig. Herman Ottó Intézet, Tizenöt év foglalkoztatási tárgyú kutatásai, Miskolc

Hadjimichalis, C., Hudson, R. (2014): Contemporary Crisis Across Europe and the Crisis of Regional Development Theories. Regional Studies 1., 208-218. https://doi.org/10.1080/00343404.2013.834044

Hajdu T., Hermann Z., Horn D., Varga J. (2019): A közoktatás indikátorrendszere 2019. MTA Közgazdaságés Regionális Tudományi Központ, Budapest https://www.mtakti.hu/wp-content/uploads/ 2020/01/A_kozoktatas_indikatorrendszere_2019.pdf (Letöltés: 2020.08.22.)

Havas G. 2008: Esélyegyenlőség, deszegregáció. In: Fazekas K., Köllő J., Varga J. (szerk.): Zöld könyv a magyar közoktatás megújitásáért. ECOSTAT, Budapest, 121-138.

Hermann Z. (2008): Hogyan értelmezzük az iskolarendszer minőségi mutatóit nemzetközi összehasonlításban? In: Fazekas K. (szerk.): Közoktatás, iskolai tudás és munkapiaci siker. MTA Közgazdaságtudományi Intézet, Budapest, 43-72.

Hermann Z., Varga J. (2018): Jelentkezés és felvétel a középfokú oktatásba. In: Fazekas K., Csillag M., Hermann Z., Scharle Á. (szerk.): Munkaerőpiaci tükör 2018. Közgazdaság- és Regionális Tudományi Kutatóközpont, Budapest, 59-62. 
Hermann Z. (2018): A középfokú iskolatípus hatása a tanulói teljesítményekre. In: Fazekas K., Csillag M., Hermann Z., Scharle Á. (szerk.): Munkaerőpiaci tükör 2018. Közgazdaság- és Regionális Tudományi Kutatóközpont, Budapest, 53-58.

Hermann Z., Horn D., Köllő J., Sebők A., Semjén A., Varga J. (2018): Szövegértési és matematikai kompetencia hatása a keresetre és foglalkoztatási esélyekre. In: Fazekas K., Csillag M., Hermann Z., Scharle Á. (szerk.): Munkaerőpiaci tükör 2018. Közgazdaság- és Regionális Tudományi Kutatóközpont, Budapest, 45-52.

Imre A. (2005): A felekezeti iskolák jellemzői a statisztikai adatok tükrében. Educatio, 3,. 475-491.

Köllő J., Sebők A. (2018): Lakóhely szerinti különbségek a nem tanuló és nem dolgozó tizenévesek arányában a tankötelezettségi kor leszállítása előtt és után. In: Fazekas K., Csillag M., Hermann Z., Scharle Á. (szerk.): Munkaerőpiaci tükör 2018. Közgazdaság- és Regionális Tudományi Kutatóközpont, Budapest, 124-127.

Kertesi G., Kézdi G. (2009): Általános iskolai szegregáció Magyarországon az ezredforduló után. Közgazdasági Szemle, 11., 959-1000.

Lang, T., Henn, S., Ehrlich, K., Sgibnev, W. (2015): Understanding New Geographies of Central and Eastern Europe. In: Lang, T., Henn, S., Ehrlich, K., Sgibnev, W. (eds.): Understanding Geographies of Polarization and Peripheralization. Perspectives from Central and Eastern Europe and Beyond. Palgrave Macmillan, UK, 1-21.

Lipták K. (2020): A közfoglalkoztatás jelentősége Borsod-Abaúj-Zemplén megye rurális településein. Tér és Társadalom, 4., 100-121. https://doi.org/10.17649/TET.34.4.3299

Martonfi Gy. (2009): A TISZK-rendszer kiépülése 2007-2008-ban. Szakképzési Szemle, 4., 403-433.

Molnár Gy. (2018): Fiatalok a közfoglalkoztatásban, különös tekintettel a középiskolai lemorzsolódásra. In: Fazekas K., Csillag M., Hermann Z., Scharle Á. (szerk.): Munkaerőpiaci tükör 2018. Közgazdaság- és Regionális Tudományi Kutatóközpont, Budapest, 114-119.

Nagy, E., Timár, J., Nagy, G., Velkey, G. (2015): The Everyday Practices of the Reproduction of Peripherality and Marginality in Hungary. In: Lang, T., Henn, S., Ehrlich, K., Sgibnev, W. (eds.): Understanding Geographies of Polarization and Peripheralization. Perspectives from Central and Eastern Europe and Beyond. Palgrave Macmillan, UK, 135-155.

Peck, J. (2016): Macroeconomic geographies. Area Development and Policy 3., 305-322. https://doi.org/ $10.1080 / 23792949.2016 .1237263$

Pusztai G. (2009): A társadalmi tóke és az iskola. Oktatás és társadalom 3. Új Mandátum Kiadó, Budapest

Radó P. (2018): A közoktatás szelektivitása, mint a roma szegregáció általános kontextusa. In: Fejes J., Szücs N. (szerk.): Én vétkem. Helyzetkép az oktatási szegregációról. Motiváció Oktatási Egyesület, Szeged, 31-56.

Rodriguez-Pose, A. (2018): The revenge of the places that don't matter (and what to do about it). Cambridge Journal of Regions, Economy and Society, 1., 189-209. https://doi.org/10.1093/cjres/rsx024

Sheppard, E. (2018): Heterodoxy as Orthodoxy: Prolegomenon for Geographical Political Economy. In: Clark, G., Feldmann, M., Gertler, M., Wójcik, D. (eds.): The New Oxford Handbook of Economic Geography. Oxford University Press, Oxford, 159-178. https://doi.org/10.1093/oxfordhb/ 9780198755609.013.9

Soja, E. (2010): Seeking Spatial Justice. University of Minnesota Press, Minneapolis https://doi.org/ 10.5749/minnesota/9780816666676.001.0001

Szarvák T. (2002): A foglalkoztatási alrendszer helyzete a Közép-Tiszavidéken. In: G. Fekete É. (szerk.): A tartós munkanélküliség kezelése vidéki térségekben. MTA RKK Vidékfejlesztési Műhely, Miskolc, Pécs, 215-230.

Velkey G. (2011): A középfokú képzés területi rendszerének változása és továbbfejlesztése. Tér és Társadalom, 3., 60-79. https://doi.org/10.17649/TET.25.3.1930

Velkey G. (2013): Dinamikus egyensúlytalanság: A hazai közoktatási rendszer szétesése, felforgatása és a konszolidáció esélye. MTA KRTK RKI, Budapest, Pécs, Békéscsaba

Velkey G. (2019a): Térbeli-társadalmi egyenlőtlenségek és újratermelésük az alapfokú oktatás hazai rendszerében. Tér és Társadalom, 4., 104-131. https://doi.org/10.17649/TET.33.4.3191

Velkey G. (2019b): Területi jellemzők és legfontosabb változásaik a hazai közoktatás, köznevelés rendszerében. Opus et Educatio, Munka és Nevelés 6, 1., 15-23. https://doi.org/10.3311/ope.291 
Zolnay, J. (2018): Commuting to segregation. The role of pupil commuting in a Hungarian city: between school segregation and inequality. Review of Sociology 4., 133-151. http://szociologia.hu/dynamic/szociologia_2018_04_133_151_oldal.pdf (Letöltés: 2019. 10. 22.) 